\title{
THEORY AND THE DOCTRINAL INTERNATIONAL LAWYER
}

\author{
Roger O'Keefe*
}

\section{A. INTRODUCTION}

How to lose friends and influence people prejudicially? Say 'theory' to a doctrinal international lawyer. Choose your target particularly unwisely and you may even have her reaching for her gun. At least this is the stereotype. The popular image, especially among theorists, is that 'black-letter' international lawyers are hostile to theoretical approaches to their field. Like many popular images, there is a grain of truth in it. Ditto, it is a caricature. Doctrinal international lawyers are more latitudinarian than infamy allows. Some of their best friends are theorists, while some go so far as to dabble in the black arts themselves. It takes all sorts.

Most doctrinal international lawyers credit a good argument when they see it, and theoretical approaches to international law offer a host of good arguments. They produce some duds as well (but in this they hold no monopoly). It depends on the theory and the theorist. More precisely, and leaving aside the question of execution implicit in the question of the theorist, the persuasiveness and ultimately the benefit to the doctrinal international lawyer of a given theoretical approach to the field depend on a complex calculus of often-overlapping criteria, such as whether the theory is explanatory, critical, prescriptive, or ideal and, more fundamentally, whether it goes to the lawyer's tasks of identifying, interpreting and applying the law or to the legislator's task of embodying its raw content in the first place.

What follows focuses on the benefit, rather than the persuasiveness, to doctrinal international lawyers of theoretical approaches to public international law. Its chief concern is with tangible benefit, although the intangible rates an important mention. Its brief reflections are impressionistic, and are from the perspective of an out-and-proud doctrinal international lawyer, albeit one with an amateur interest in theory. The term 'doctrinal international lawyer' is used throughout to refer to those practitioners lato sensu-judges (both international and, in relevant cases, national), legal counsel (both independent and institutional), other legal officers of states, international organisations, and international courts and tribunals, and the like - and scholars of public international law who cleave to the discipline's mainstream legal positivism.

\footnotetext{
* Roger O'Keefe is Professor of Public International Law at University College London.
} 


\section{B. 'THEORY'}

Despite a tendency to treat it as coterminous with critical theory, 'theory' embraces a multitude of sins, so to speak. Insofar as we are talking about law, there is specifically legal theory and there are legal applications of other theoretical branches of the social sciences such as political theory, philosophy, hermeneutics, linguistics, semiotics, aesthetics, and anthropology. Nor are theory and legal doctrine diametrically opposed. The inductive derivation of legal principle from the multiplicitous specificity of rules and practice is a form of theorising: Anzilotti, Ago, and Arangio-Ruiz can be considered theorists, albeit of a different sort from Kelsen, Kennedy, and Koskenniemi, let alone Bukharin, Benjamin, and Baudrillard. The focus here, however, is not on what might be called 'doctrinal theory'. It is on legal theory in the sense of theoretical jurisprudence and on the application to international law of other social scientific theory.

\section{THE SYSTEMIC CONSTRAINTS ON THE PRACTICAL BENEFIT OF THEORY TO THE DOCTRINAL INTERNATIONAL LAWYER}

Public international law as currently conceived is a positivist system in which the two foremost formal sources of law, namely treaty and customary international law, are not the lawyer's, including the judge's, to posit. Treaties are concluded chiefly by states (via their governments) and international organisations (via their secretariats), while the customary international lawmaking process remains, at least formally, the preserve of states alone. Even more fundamentally, states alone enjoy the authority to create and modify the system's rules of recognition, chief among them the rules on the creation of customary international law and the rules on the interpretation and application of treaties. Granted, the formal sources of international law recognised by states extend to 'the general principles of law recognized by civilized nations', ${ }^{1}$ a 'reservoir of principles' ${ }^{2}$ into which the international adjudicator is authorised to dip failing clear provision for a rule of decision by treaty or custom, and to judicial decisions themselves, which constitute 'subsidiary sources for the determination of rules of [international] law, ${ }^{3}$ meaning that they may be looked to as at least persuasive authority for the content of a treaty-based or customary rule or a general principle of law. The fact remains, however, that the authorised legislators, as it were, in the international legal system are first and foremost states and, in terms of treaty law, the parties to the treaty, be they states, international organisations or one of the few other competent entities. Within this system, the

\footnotetext{
${ }^{1}$ Statute of the International Court of Justice, art 38(1)(c).

${ }^{2}$ Humphrey Waldock, 'General Course on Public International Law' (1962) 106 Recueil des Cours 1, 61.

${ }^{3}$ Statute of the International Court of Justice, art 38(1)(d).
} 
formal role of the lawyer, including the judge, is limited to the identification, interpretation and application of the operative rules by faithful reference to the system's rules of recognition. This is not to suggest that this role is purely mechanical or to deny that the judicial application of a rule generates a further rule. It is simply to draw a line between the circumscribed creative acts of the lawyer and the sovereign creative acts of the legislator.

Any theoretical approach to international law that does not accept as given and adequately reckon with these systemic constraints under which international lawyers act is of little concrete use to them, whatever its more abstract merits or its salience to the stateswoman. ${ }^{4}$ To be of practical professional benefit to international lawyers, a theoretical approach must take accurate account of the room for 'free play' ${ }^{5}$ afforded them by the rules of the game. The upshot is that, whatever its intrinsic or other intangible value ${ }^{6}$ or its tangible value to others, much critical and prescriptive theory is of no tangible value to international lawyers either in that it is directed, self-consciously or otherwise, towards matters - the essential content of specific rules, fundamental concepts and principles of the international legal system itself, and so on - which are beyond the province of the lawyer entirely or in that it overestimates the discretion properly available to him within his province.

\section{THEORY AND THE PROBLEM OF BAD LAW}

It is not uncommonly the case that a given theoretical take, be it prescriptive or descriptive, on an aspect of international law is perfectly plausible on its own terms and not inherently beyond the international lawyer to take on board but is premised on a flawed understanding of the relevant law. In such instances its weak foundations will undermine its utility to the lawyer. Indeed, it may well be that the whole house of cards collapses. This is not to say that theorists cannot do black-letter law. The seductive temptation, however, which even the immortal Austrian was unable at times to resist, ${ }^{7}$ is to fit the evidence to the theory. There is a sense too in which international law is especially open to misconstruction even in the utmost good faith, insofar as the international legal system is heavily dependent for its functioning on subtle,

\footnotetext{
${ }^{4}$ It is true that the stateswoman may look to the international lawyer for advice as to the better position for her state or international organisation to take on a point of international law, in which case the room allowed the lawyer will not be formally limited by systemic constraints. But one would rarely expect the policy advice sought of the lawyer to go beyond the more-or-less legal. 'Pure' policy questions are likely to be reserved to the stateswoman or others.

${ }^{5}$ Hans-Georg Gadamer, Truth and Method (Joel Weinsheimer and Donald G Marshall trs, first paperback edn, Bloomsbury 2013), 540.

${ }^{6}$ For the intangible good of even impracticable theory to even, and perhaps especially, the most diehard blackletter international lawyer, see below.

${ }^{7}$ See, generally, Hans Kelsen, Principles of International Law (Rinehart \& Co 1952).
} 
informal, inter-subjective processes of collective legal-factual appreciation, the accurate reading of which calls for a hard-won phronesis. Whatever the explanation, the frustrating fact is that much attractive theory is built on bad law and, as such, is of little tangible benefit to anyone, least of all the lawyer.

\section{E. THE SORTS OF THEORY OF MOST TANGIBLE BENEFIT TO THE DOCTRINAL INTERNATIONAL LAWYER}

Given the systemic constraints under which international lawyers work, the sort of theory most likely to be of practical use to them is either avowedly explanatory or, although avowedly ideal, has explanatory value. Explicitly or effectively explanatory theory can serve to elucidate what the hidden sense-over and above any rationale or rationales offered by the system itself or its actors - of a specific rule of international law might be, lending a purposiveness or deeper purposiveness to what may appear an arbitrary or at least unconvincingly rational normative arrangement.

The elaboration of a plausible 'thick' rationale for an applicable positive rule may in turn have an implicitly prescriptive import. It may serve to defend rhetorically, should rhetorical support be thought necessary, a systemically-mandated reading or application of the rule against superficially attractive anti-formalist arguments or to suggest the preferable in policy terms, should policy be thought relevant, of equally available doctrinal options. The practical purchase of both benefits may be limited, just as the practical purchase in the first place of anti-formalist or other policy-based arguments may be limited, in the context of judicial proceedings, but academic doctrinal international lawyers may be more receptive.

Take, for example, the customary international rules on treaty interpretation reflected in articles 31 and 32 of the Vienna Convention on the Law of Treaties, which privilege the text and its subsequent application by states parties over historical evidence of the intention of the drafters. Populist challenges to the relegation of the travaux préparatoires to the status of subsidiary means of interpretation may hold a superficial attraction, leading in some quarters to a temptation to 'relax' the interpretative scheme mandated by customary international law in favour of the supposed 'original intent' of the drafters. A doctrinal scholar of international law seeking to defend the orthodoxy may find it useful to go beyond simple appeal to positive law and to call in aid the philosophical hermeneutics of Hans-Georg Gadamer to strengthen 
her position. ${ }^{8}$ Not dissimilarly, the positive requirement to take particular account in the identification of a rule of customary international law of the position of states whose interests are specially affected ${ }^{9}$ finds support in the analogical application to the interstate level of the discourse theory of Jürgen Habermas. ${ }^{10}$ Even more fundamental rules of the international legal system, such as the sovereign equality of states and its corollary in the prohibition on intervention by one state in the domestic affairs of another, find a measure of justification in John Rawls's application of his theory of justice to the interstate system. ${ }^{11}$ A wide variety of specific treaty regimes too resonate in social scientific theory. By way of more or less random example, a degree of policy justification for both the Convention for the Safeguarding of the Intangible Cultural Heritage 2003 and the Convention on the Protection and Promotion of the Diversity of Cultural Expressions 2005 can be found in the cultural theory of Theodor Adorno ${ }^{12}$ - although the same theory can be looked to for a plausible critique of the same regimes. ${ }^{13}$

\section{F. THE INTANGIBLE BENEFIT OF THEORY TO THE DOCTRINAL INTERNATIONAL LAWYER}

Perhaps the greatest benefit to the doctrinal international lawyer of theoretical approaches to international law is not to be found in the mundane realm of the tangible. It may even at times be unconscious. This benefit is perspective.

Exposure to even the least plausible, least practically useful of the many and varied theoretical takes on the field at the very least makes the doctrinal international lawyer aware that his - or, more accurately, the presently-configured international legal system's - is not the only way of approaching international law. Others can be imagined. A certain type of theory may equally suggest to the black-letter international lawyer that the system's current way of doing things or specific rules forming part of the current corpus have their intellectual, moral,

\footnotetext{
${ }^{8}$ See eg Gadamer (n 5). In an eerie coincidence, the present author, who was at the time simultaneously completing a different piece incorporating insights from Gadamer, struck upon this example before discovering that the present issue of the UCL Journal of Law and Jurisprudence contains a contribution on precisely this topic. See Katayoun Hosseinnejad, 'On the Nature of Interpretation in International Law', (2015) 4(2) UCLJLJ 225; Consider also William Shakespeare, Hamlet, Act I, scene V, lines 167-8.

${ }^{9}$ See, inter alia, North Sea Continental Shelf (Federal Republic of German v/Denmark; Federal Republic of Germany v Netherlands) (Judgment) 1969 ICJ Rep 42, paras 73-74.

${ }^{10}$ See eg Jürgen Habermas, Between Facts and Norms. Contributions to a Discourse Theory of Law and Democracy (William Rehg tr, MIT Press 1996).

${ }^{11}$ See 'The Law of Peoples' in John Rawls, The Law of Peoples, with 'The Idea of Public Reason Revisited' (Harvard University Press 1999).

${ }^{12}$ See eg 'Culture industry reconsidered' in Theodor W Adorno, The culture industry. Selected essays on mass culture (J M Bernstein ed, Routledge 1991) 85.

${ }^{13}$ See eg 'Culture and administration' in ibid, 93.
} 
or other extra-legal flaws. It may even be that theory highlights to the international lawyer that law itself is only one approach among many, and a limited approach at that, to human selfordering and ultimately to the promotion of human flourishing. Said lawyer may be in no position to do the slightest thing about any of this. But the realisation ought to prove salutary. It ought to serve as an antidote to - or, if administered to the young responsibly in very small doses, vaccination against - a range of attitudinal disorders to which the black-letter international lawyer is, on the epidemiological evidence, professionally susceptible, from naïve faith to scornful arrogance. In short, it should inspire a sober humility.

Conversely, exposure to and, crucially, critical engagement with theoretical approaches to international law can and should lead the doctrinal international lawyer to understand and value what doctrinal international law's distinctive contribution is and can be. Perspective cuts both ways. After all, legal positivism is itself a theory. Good theory, legal and otherwise, can open the black-letter international lawyer's eyes to the wider justifications for and meaning of her professional practices. Bad theory can be just as instructive. The lesson can and should be that the methodological commitments of the doctrinal international lawyer need not be cause for embarrassment.

\section{G. CONCLUSION}

Theoretical approaches to international law are a good thing. Some are better than others. Some are of more benefit than others to doctrinal international lawyers. But all at least invite such lawyers to expand their intellectual horizons and to use parts of their brains that they may not have used for some time.

Ultimately what stands to benefit both theoretical and doctrinal international lawyers, as well as international law as an ecumenical whole, is close, mutually respectful, and openminded co-operation between the two. ${ }^{14}$

\footnotetext{
${ }^{14}$ For an excellent example of the benefits of such co-operation, see Samantha Besson and John Tasioulas (eds), The Philosophy of International Law (OUP 2010).
} 